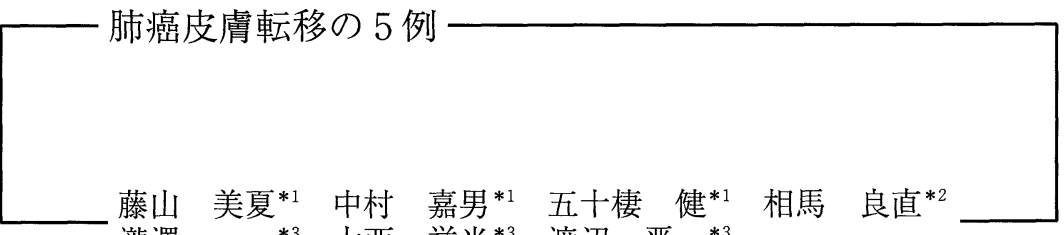
㴰澤 一*3 大西 誉光*3 渡辺 晋一*3

\title{
Five cases of metastatic lung carcinoma to skin
}

Mika FUJIYAMA *1, Yoshio NAKAMURA *1, Ken IOZUMI *1, Yoshinao SOMA *2, Hajime TAKIZAWA *3, Takamitsu OHNISHI *3, Shinichi WATANABE *3

*1 Department of Dermatology, Tokyo Metropolitan Police Hospital

*2 Department of Dermatology, St. Marianna University School of Medicine

*3 Department of Dermatology, Teikyo University School of Medicine

We report 5 cases of metastatic lung carcinoma to the skin. The 5 patients, 4 male and one female, ranged in age from 35 to 80 years. Clinical manifestations were intracutaneous or subcutaneous nodules, which were located on various sites: the head, trunk, and inguinal region and finger. Histologic examination revealed 3 cases of adenocarcinoma and 2 cases of small cell carcinoma. Duration between occurrence of skin metastasis and death was from 4 to 14 months. No expression of cytokeratin 20 (CK20) was observed in any cases. The results suggested that CK20 is a useful marker in the differentiation between merkel cell carcinoma and skin metastasis of small cell carcinoma, or between metastasis from the lung and that from the gastrointenstinal (GI) tract because merkel cell carcinoma and adenocarcinoma of GI tract express CK20 in general. [Skin Cancer (Japan) $2000 ; 15$ : 179-184]

Key words : metastatic lung carcinoma to skin, CK20

\section{はじめに}

悪性新生物による死亡者のうち肺癌の占める 割合は男女とも年々増加しており，我が国の 1997 年の統計では男が $21.4 \%$ で第 1 位，女は

*1 東京警察病院皮膚科

*2 聖マリアンナ医科大学皮膚科

*3 帝京大学皮膚科
$12.3 \%$ で第 4 位となっている ${ }^{1)}$ 。このため肺癌の 皮膚転移も増加しており，内臟悪性腫瘍の皮膚 転移の原発巣として肺癌を第 1 位にあげる報告 が近年多くみられ ${ }^{2)-5)}$ ，今後もなお増加してい くものと予想される。今回，当科で経験した肺 癌皮膚転移の 5 例を報告する。いずれの症例も メルケル細胞癌や消化管癌で発現するとされる CK20の発現はみられず，鑑別に有用なマー カーとなりえた。 


\section{症例}

症例 $1: 35$ 歳, 男性

初 診: 1997 年 9 月 16 日

主 訴：腹部の結節

既往歴：特記すべきことなし。

家族歴：特記すべきことなし。

現病歴：1997 年 4 月より胸痛が出現し, 肺癌 を疑われて同年 7 月に近医より当院内科を紹介 され，TBLBを行い肺小細胞癌と診断された。 化学療法と放射線療法を施行中の同年 9 月上旬 に，腹部に結節が出現したため当科を紹介され た。

現 症: 左腹部に直径 $5 \mathrm{~mm}$ 大の皮内加皮 下の結節を認めた。表面の皮膚は常色で，結節 は弾性硬で球状に触知され，圧痛を伴っていた (図 1a)。

病理組織学的所見：真皮から皮下組織にかけ て充実性胞巣が近接して多数認められた。腫瘍 細胞は主にクロマチンに富んだ核を有する小型 の細胞で，大型細胞も一部に混在し，核分裂像 が多くみられた（図 1b)。小細胞癌の皮膚転移 と診断した。

さらに, その 3 カ月後に, 腹部に新たに 3 個 の結節が出現し, 組織像より皮虐転移と診断し

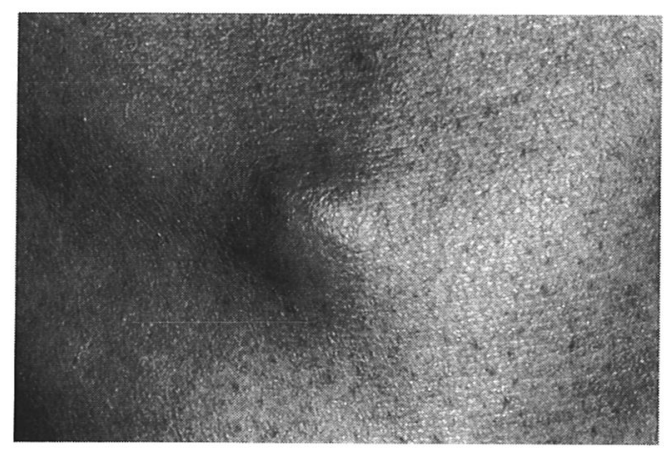

図 1a. 左腹部に直径 $5 \mathrm{~mm}$ 大の皮内から皮下の結節 を認めた。皮表は常色で圧痛を伴っていた
た。

経 過：化学療法を施行するも脳, 肝, 腹腔 リンパ節転移が出現し, 肝, 腎不全にて 1998 年 1 月に永眠した。

症例 $2: 53$ 歳, 男性

初診: 1997 年 5 月 17 日

主 訴: 右側胸部の腫瘤

既往歴：白内障, 脳出血

家族歴：特記すべきことなし。

現病歴：1997 年 2 月に労作時呼吸困難を自覚 し，さらにこの頃より右側胸部の皮下腫瘤に気 付くも放置していたところ，徐々に増大した。 同年 5 月 15 日に両側胸水で当院内科に緊急入 院し, 肺癌を疑われた。内科より腫瘤の精査を 依頼された。

現 症：右側胸部に大きさ $8 \times 7 \times 2 \mathrm{~cm}$ の正 常皮面より半球状に隆起する弾性硬の皮下腫瘤 を認めた。表面の皮膚は常色で，腫瘤は凸凹不 整に触知され，下床との可動性はなかった（図 2a)。

病理組織学的所見：皮虐生検像では，真皮内 に円柱状の異型細胞から構成された穊状あるい は管腔状の腫演塊が多数認められた（図 2b）。

TBLB にて肺胞上皮癌が確認されたため，皮 膚病理所見よりその皮膚転移と診断した。

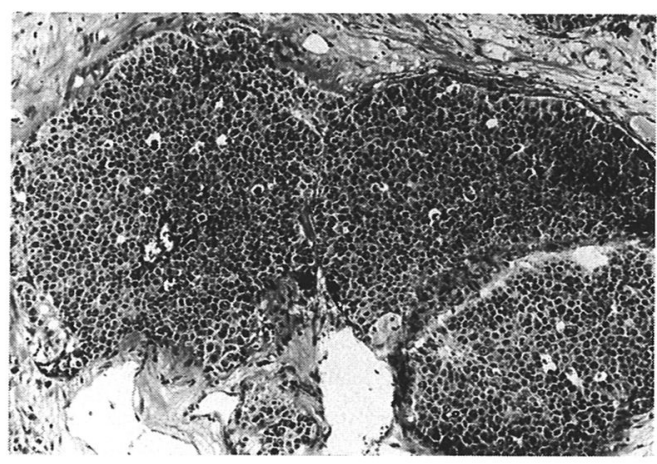

図 1b. 真皮から皮下組織にかけて充実性胞巣が近接 して多数認められた. 腫瘍細胞は主にクロマ チンに富んだ核を有する小型の細胞で, 大型 細胞も一部に混在し, 核分裂像が多くみられ た 


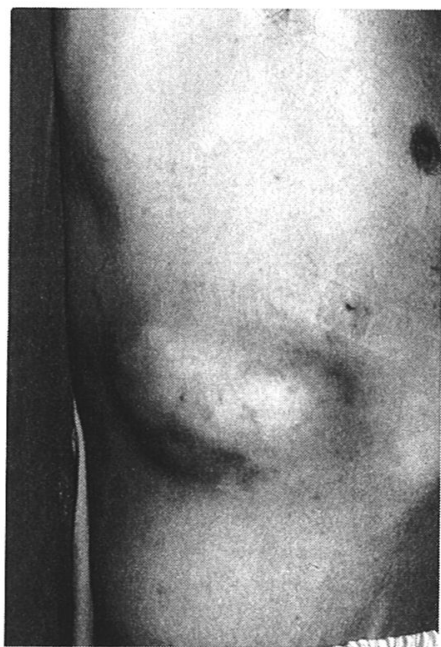

図 2a. 右側胸部に大きさ $8 \times 7 \times 2 \mathrm{~cm}$ の正常皮面よ り半球状に隆起する弾性硬の皮下腫瘤を認 めた

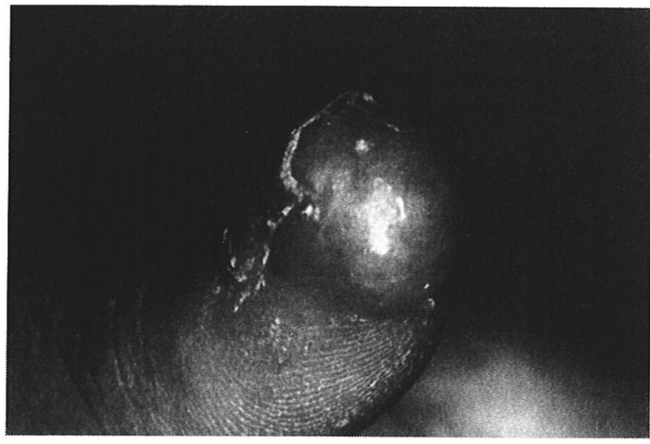

図 3a. 左母指尖に $10 \times 15 \mathrm{~mm}$ 大の弾性軟の広基性球 状の結節が認められ，発赤，腫脹と圧痛を伴 っていた

経 過：胸水，心囊液を利尿剂，胸水穿刺に て対処していたが，同年 9 月 30 日に呼吸不全 をきたし永眠した。

症例 $3: 65$ 歳, 男性

初 診: 1994 年 10 月 20 日

主 訴: 左母指の結節

既往歴：高血圧症

家族歴：特記すべきことなし。

現病歴：1994 年 1 月に健診で胸部異常陰影を 指摘されたため内科を受診し，擦過細胞診にて 肺小細胞癌と診断された。化学療法施行中の同

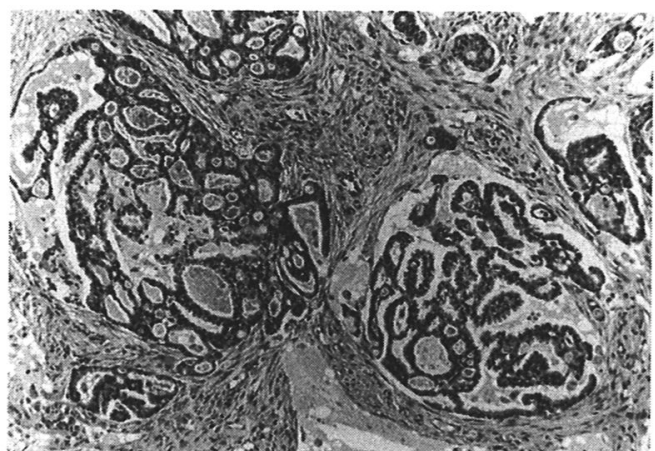

図 2b. 真皮内に円柱状の異型細胞から構成された笁 状あるいは管腔状の腫崵塊が多数認められた

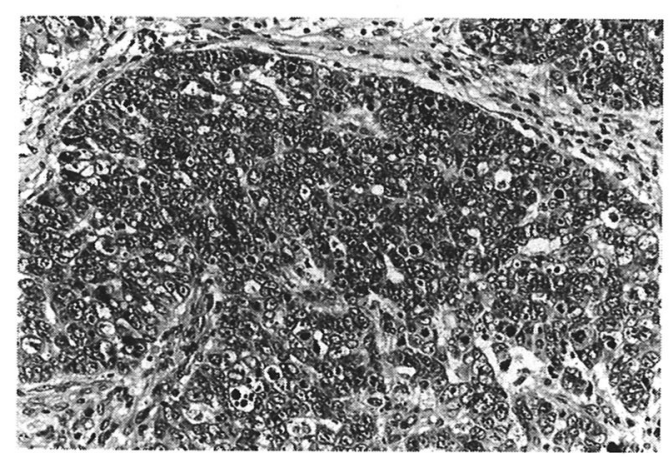

図 3b. 真皮から皮下組織にかけて充実性胞巣が存在 し, 腫瘍細胞は類円形の細胞で異型性が強く 核分裂像も多数みられた

年 8 月中旬に左母指に皮疹が出現したが放置し ていたところ，増大し圧痛を伴うようになった ため当科を受診した。

現 症：左母指尖に $10 \times 15 \mathrm{~mm}$ 大の弾性軟の 広基性球状の結節が認められ，発赤，腫脹と圧 痛を伴っていた（図 3a）。

病理組織像は症例 1 と同様で（図 3b）肺小細 胞癌皮膚転移と診断した。

経 過：本人が amputation，植皮などの姑息 手術を希望しなかったため外用処置のみで経過 観察していたところ，腫瘍は比較的急速に増大 し，3カ月後には野球ボール大になった（図 
3c)。このさらに3カ月後に, 原病による呼吸不 全のために永眠した。

症例 $4: 80$ 歳, 男性

初 診: 1995 年 11 月 6 日

主 訴：頭部，顔面，鼠䅡部の結節

既往歴: 膵炎, 狭心症

家族歴：特記すべきことなし。

現病歴：1995 年 8 月に頭部, 10 月に額部と鼠 頚部の結節に気付くも放置していたところ，そ の後徐々に増大した。左頬部の結節には気付い ていなかった。同年 10 月に右胸水貯留のため 内科で精査を行い, 胸部 X線, CTにて異常院影 と骨破壊像を認め, 胸水検査にて class（V) (adenocarcinoma) であったことから，肺腺癌

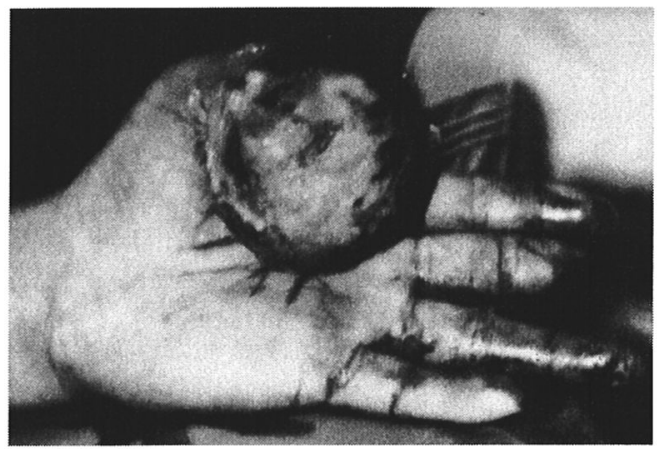

図 3c. 当科初診 3 力月後の臨症像 腫瘍は野球ボール大に増大した
と診断された。結節の精査につき当科を紹介さ れた。

現 症：頭頂部，額部，左煩部掞よび鼠䅡部 に直径 6 13mm 大の弾性硬で可動性のない半 球状の結節を認めた。結節の表面は易出血性で 頭頂部の結節は圧痛を伴っていた。

額部の結節を生検し, 症例 2 と同様に異型細 胞からなる曹胞腺管構造が真皮内に多数みら れ，肺腺癌の皮膚転移と診断した。

経 過：放射線照射を施行したが, 1996 年 4 月に呼吸不全のため永眠した。

症例 $5 ： 80$ 歳, 女性

初診: 1997 年 4 月 11 日

主 訴：頭部と背部の結節

既往歴：卵巣囊腫，虫垂炎

家族歴：同胞に癌が多いというが不明。

現病歴：1994 年 10 月に肺炎で入院した際に 肺癌が発見された。同年 12 月に右肺上葉切除 術を施行し，その後放射線療法を施行していた が 1997 年 3 月上旬に頭部に, 3 月中旬には背部 に結節が出現したため当科を紹介された。

現 症：頭部に直径 $3 \mathrm{~mm}$ と $7 \mathrm{~mm}$ の毛細血管 拡張を伴う小結節がみられ，上背部左側に $20 \times$ $16 \mathrm{~mm}$ 大の弾性軟の皮下腫瘤を認めた。

頭部の結節のひとつと背部の結節を生検し, 症例 2 および 4 と同様な所見から肺腺癌の皮膚

表 1 . 自検例 5 例の概要

\begin{tabular}{|c|c|c|c|c|c|c|c|c|c|}
\hline 症例 & 年齢 - 性 部位 & 数 & 大きさ & 臨床型 & 病理組織 & $\begin{array}{l}\text { 他の } \\
\text { 転移部位 }\end{array}$ & 肺癌の診断 & 皮膚科初診 & $\begin{array}{l}\text { 皮膚転移診断 } \\
\text { 後の生存期間 }\end{array}$ \\
\hline 1 & 35歳·男 腹部 & 4 & $\begin{array}{c}\text { 直径 } \\
5 \sim 16 \mathrm{~mm}\end{array}$ & $\begin{array}{l}\text { nodular } \\
\text { type }\end{array}$ & 小細胞癌 & $\begin{array}{c}\text { 骨, 腦, 副堅 } \\
\text { リンパ節 }\end{array}$ & 1997 年7月 & 1997 年9月 & 4 ヶ月 \\
\hline 2 & 53 歳・男 側胸部 & 1 & $\begin{array}{c}80 \times 70 \times 20 \\
\mathrm{~mm}\end{array}$ & $\begin{array}{l}\text { nodular } \\
\text { type }\end{array}$ & 腺癌 & 骨, 腷 & 1997 年5月 & 1997 年5月 & 4 ヶ月 \\
\hline 3 & 65歳·男 右母指 & 1 & $10 \times 15 \mathrm{~mm}$ & $\begin{array}{l}\text { nodular } \\
\text { type }\end{array}$ & 小細胞癌 & 骨, 腷 & 1994 年 2 月 & 1994年10月 & 6ヶ月 \\
\hline 4 & 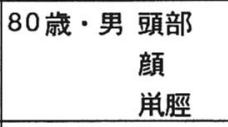 & $\begin{array}{l}1 \\
2 \\
2 \\
\end{array}$ & $\begin{array}{c}10 \times 11 \mathrm{~mm} \\
5 \mathrm{~mm} \cdot 7 \mathrm{~mm} \\
9 \mathrm{~mm} \cdot 13 \mathrm{~mm} \\
\end{array}$ & $\begin{array}{l}\text { nodular } \\
\text { type }\end{array}$ & 腺癌 & 骨 & 1995年10月 & 1997年11月 & 5 ヶ月 \\
\hline 5 & $\begin{array}{r}80 \text { 痛·女 頭部 } \\
\text { 背部 }\end{array}$ & $\begin{array}{l}2 \\
1 \\
\end{array}$ & $\begin{array}{c}3 \mathrm{~nm} \cdot 7 \mathrm{~mm} \\
20 \times 16 \mathrm{mmmm}\end{array}$ & $\begin{array}{l}\text { nodular } \\
\text { type }\end{array}$ & 腺癌 & $\begin{array}{l}\text { 脳, 肝 } \\
\text { リンパ節 }\end{array}$ & 1994 年 10 月 & 1997 年 4 月 & 1 年2 ヶ月 \\
\hline
\end{tabular}


転移と診断した。

経 過：脳，肝，腹腔リンパ節転移も出現 し，1998 年 5 月に呼吸不全のため永眠した。

免疫組織学的所見：症例 $1 \sim 5$ に対して抗开 イトケラチンモノクロナール抗体を用いて $\mathrm{ABC}$ 法にて免疫染色を行った。CK8, 18 を認識 する CAM5.2 抗体では 5 例の全ての腫瘍細胞に 陽性所見がみられたが，腺癌の 1 例では paranuclear staining pattern を示した。CK7 を 認識する抗体でも同様の染色態度を示したが, 肺小細胞癌の転移例では染色性が弱かった。 CK20の発現はいずれの例でもみられなかった (表 1 )。

\section{考察}

近年の肺癌の増加 ${ }^{1)}$ とともに, 内臓悪性腫瘍 の皮膚転移では肺癌を原発とする例の増加が報

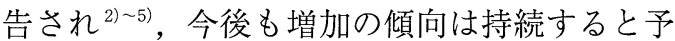
想される。当科においても過去 5 年間に 10 例 の内臓悪性腫瘍の皮膚転移を経験したが，肺癌 を原発とする皮䖉転移例は 5 例で最も多く，そ の他に胃癌 2 例, 乳癌 2 例, 腎癌 1 例がみられ た。

肺癌皮膚転移の 5 症例の概要を表に示す。患 者は 35 歳から 80 歳の男性 4 例と 80 歳の女性 1 例で平均年齢は，62.6 歳だった。皮膚転移部 位は一般に，原発臓器を覆う皮膚に最も多くみ られるが, 肺癌においては, 体幹の他, 頭澒部, 顔面など遠隔部にも多く認められる ${ }^{4 / 5)}$ 。実験例 では，5例中体幹が 2 例，頭部・顔面が 1 例， 頭と体幹の両方にみられたのが 1 例の他，手指 に 1 例認められた。内臓悪性腫瘍の皮膚転移は 臨床形態により, nodular type, inflammatory type, sclerodermoid type の 3 型に分類されてお $\eta^{6)}$, 頻度としては nodular type が多く ${ }^{4) 5}$, 多く は多発性であるとされている7)。実験の 5 例は 全例が nodular type で，そのうち 2 箇所以上に 認められたのは 3 例だった。肺癌皮膚転移の組 織は一般に腺癌が多く ${ }^{879)}$ ，自験例でも 5 例中 3
例が腺癌だった。また皮膚転移から原発巣が発 見される率は，山本ら ${ }^{2)}$ の報告によると 10３0\% と少なくないが，自験例では皮疹が肺 癌診断の契機となったものはなく，皮膚転移が 原発巣診断時すでに出現していたものは 2 例 で，他 3 例は約 2 力月後から 2 年 5 力月後に出 現したものであった。皮膚転移発見後の生存期 間は短く，堀ら ${ }^{10)}$ 日高ら ${ }^{8)}$ の統計ではそれぞれ 平均 4.7 力月, 8.6 力月とされている。自例では 4 力月から 1 年 2 カ月で, 平均 6.6 カ月だった。 肺癌におけるサイトケラチンの発現は，腺癌 では単層上皮型ケラチンの発現が高率にみら れ，小細胞癌では低率である ${ }^{1112)}$ 。自験の 5 例で は腺癌および小細胞癌いずれにも CK7, 8, 18 の 発現がみられたが，染色性は小細胞癌のものが 弱かった。

肺小細胞癌の皮膚転移では組織学的に悪性リ ンパ腫や小型の腫瘍細胞を主体とする悪性黒色 腫など小細胞性の悪性腫瘍との鑑別を要す る ${ }^{13)}$ 。自験例ではサイトケラチンの発現がみら れたことから間葉系の悪性腫瘍は否定的で，上 皮性の腫瘍，特にメルケル細胞癌 (Merkel cell carcinoma 以下 MCC) との鑑別が問題となっ た。MCCは病理組織学的に, 表皮と連続性のな い小細胞性の索状ないしび慢性の腫瘍塊を真皮 内に認め，電子顕微鏡的には腫瘍細胞内に存在 する有芯性の神経内分泌顆粒や核周辺にトノ フィラメント類似の微細な繊維を認めることな

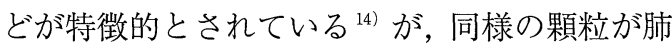
小細胞癌の皮膚転移でもみられる。

また両者は NSE, chromograninA, EMA を発 現し，頻度の差はあるが単層上皮型ケラチンの 発現もみられることょり，免疫組織学染色でも 鑑別は困難であった。しかし，正常皮膚では $\mathrm{CK} 20$ は表皮, 粘膜のメルケル細胞にのみ発現 し，MCCには発現するが, 肺小細胞癌やほかの neuroendocrine 系の腫瘍に発現がみられない ことから MCC の有用なマーカーであることが 近年多数報告されている ${ }^{1516)}$ 。一方，肺腺癌の 皮膚転移では消化管など他の内臓癌からの転移 
も鑑別として考えられるが, CK20が㓌性であ ればCK20の発現がみられる消化管（特に結 腸），尿管上皮からの転移は否定的であるとい える。実験例でも，全例がCK20に院性であっ たことより，これらの鑑別に有用と思われた。

本論文の要旨は第 62 回日本皮虐科学会東京支部 学術大会にて発表した。

\section{文献}

1）厚生統計協会：第 2 章 人口動態 2 . 死亡. 国民衛 生の動向, 46(9): 46-58, 1999.

2 ) 山本稔, 他：転移性皮膚癌の分析. 臨皮, 47(8): 653-655, 1993.

3）山本俊幸, 他: 当科に扔ける転移性皮虚癌の集 計. Skin cancer, 8(2):285-287, 1993.

4）龍崎圭一郎, 他: 群馬大学皮膚科における転移性 皮虐癌の臨床的検討。臨皮，51(7): 500-503, 1997.

5）石澤俊幸, 他：山形大学皮膚科における内臟癌皮 膚転移の統計的観察. Skin cancer, 14(2)：178-181, 36, 1999.

6) Brownstein, M.H. \& Helwig, E.B. : Spread of Tumors to the Skin. Arch. Dermatol., 107: 80-86, 1973.
7）下田祥由, 他：転移性皮膚癌. 皮膚臨床，26：463474, 1984.

8）日高利昭，他：当科における肺癌皮膚転移症例の 臨床的検討. 肺癌, 34 巻 5 号 813, 1994.

9）杉浦啓二, 他：藤田保健衛生大学病院皮膚科にお ける過去 10 年間の皮膚悪性新生物のまとめ. Skin cancer, 13(3):247-252, 1998.

10）堀真，他：転移性皮膚癌の統計的観察．西日本皮 膚, 49:304-310, 1987.

11) Kawai, T.,et al. : KM195 as an immunohistochemical marker of adenocarcinoma of the lung. Lung Cancer, 15:41-50, 1996.

12) Shy, S.W.,et al. : Small Cell Lung Carcinoma : Clinicopathological, Immunohistochemical, and Ultrastructural Study. J. Surg. Oncol., 45 : 146161, 1990.

13) Wick, M.R., Swanson, P.E. : Merkel Cell Carcinoma. Cutaneous adonexal tumors, ASCP Press, Chicago, 169-187, 1991.

14）鈴木啓之：皮虞疾患の病理 メルケル細胞癌. 病理 と臨床, 8:456, 1990.

15）岡田裕之, 他: Merker Cell Carcinoma の 1 例一抗 keratin 抗体の診断における有用性一. 日皮会誌, 105:1445-1450, 1995.

16）森勝典, 他：メルケル細胞癌の 1 例. 皮膚, $39(2)$ :173-176, 1997. 